\title{
ELECTROCHEMICAL AND MECHANICAL BEHAVIOR OF ALUMINUM AA2024-T3 COATED WITH HYBRID MATRIX CONTAINING GRAPHENE OXIDE
}

\author{
Henrique Ribeiro Piaggio Cardoso ' \\ Lilian Vanessa Rossa Beltrami ${ }^{2}$ \\ Patrícia Marcolin ${ }^{3}$ \\ Tatiane Longhi Scopel ${ }^{4}$ \\ Sandra Raquel Kunst ${ }^{3}$ \\ Lucas Madalosso de Lemos ${ }^{2}$ \\ Thuany Maraschin ${ }^{5}$ \\ Nara Regina de Souza Basso ${ }^{5}$ \\ Célia Fraga Malfatti '
}

\begin{abstract}
The aeronautics industry uses aluminum alloy AA2024-T3 due to its low density and good mechanical properties. However, this alloy requires the use of protective coatings because it does not have the corrosion and wear resistance required by the aeronautics industry. In this context, this work aims at evaluating the performanceof AA2024-T3 aluminum coated with hybrid films containing graphene oxide. The hybrid films were obtained by a dip coating process from a sol composed by tetraethoxysilane/3 (trimethoxysilylpropyl) methacrylate/cerium nitrate/ethanol/water with different concentrations of graphene oxide in suspension. The morphology was evaluated by Scanning Electron Microscopy. The corrosion resistance and wear behavior of the obtained coatings were characterized by open circuit potential, polarization curves and dry wear tests using constant force in a ball-on-plate tribometer. In the studied conditions, the metal coated with hybrid matrix films containing graphene oxide presented no changes in the corrosion resistance, but it showed a positive contribution to the wear resistance.

Keywords: Composite film; Graphene oxide; Corrosion and wear; Aluminum.

\section{COMPORTAMENTO ELETROQUÍMICO E MECÂNICO DO ALUMÍNIO AA2024-T3 REVESTIDO COM FILME HÍBRIDO CONTENDO ÓXIDO DE GRAFENO}

\section{Resumo}

A indústria aeronáutica utiliza a liga de alumínio AA2024-T3 devido a sua baixa densidade e boas propriedades mecânicas. Contudo, essa liga requer o uso de revestimentos protetores, pois não tem a resistência a corrosão e ao desgaste necessário para esta aplicação. Nesse contexto, este trabalho visa avaliar o desempenho da liga de alumínio AA2024-T3 revestida com filmes híbridos contendo óxido de grafeno. Os filmes híbridos são obtidos por processo de dip coating de um sol composto por tetraetoxisilano/3 (trimetoxisilylpropil) metacrilatonitrato de cério/etanol/água com diferentes concentrações de óxido de grafeno em suspensão. A morfologia foi avaliada por Microscopia Eletrônica de Varredura. O comportamento em relação a resistência à corrosão e ao desgaste dos revestimentos foi avaliada por potencial de

\footnotetext{
'Programa de Pós-graduação em Engenharia de Minas, Metalúrgica e de Materiais - PPGE3M, Universidade Federal do Rio Grande do Sul - UFRGS, Porto Alegre, RS, Brasil.

${ }^{2}$ Laboratório de Pesquisa em Corrosão - LAPEC, Universidade Federal do Rio Grande do Sul - UFRGS, Porto Alegre, RS, Brasil.

${ }^{3}$ Programa de Pós-graduação em Engenharia de Processos e Tecnologia - PGEPROTEC, Universidade de Caxias do Sul - UCS, Caxias do Sul, RS, Brasil.E-mail:pmarcolin@ucs.br

${ }^{4}$ Laboratório de Corrosão - LCOR, Universidade de Caxias do Sul - UCS, Caxias do Sul, RS, Brasil.

${ }_{5}^{5}$ Programa de Pós-graduação em Engenharia e Tecnologia de Materiais - PGETEMA, Pontifícia Universidade Católica do Rio Grande do Sul - PUCRS, Porto Alegre, RS, Brasil.
} 
circuito aberto, curvas de polarização e testes de desgaste a seco com força constante em um tribômetro ball-on-plate. Nas condições estudadas, o metal revestido com filmes híbridos contendo óxido de grafeno não apresentou mudanças na resistência a corrosão, mas mostrou uma contribuição positiva na resistência a abrasão.

Palavras-chave: Filme compósito; Óxido de grafeno; Corrosão e desgaste; Alumínio.

\section{INTRODUCTION}

This paper discusses recent topics involving graphene oxide, composite films and their use in aviation. Considering environmental problems with the coating material used in aircraft fuselages, this paper aims at obtaining a new protective film that is both in agreement with new environmental standards and more adequate in relation to corrosive effects.

The current $\mathrm{Al}$ alloy coating system used in aviation is composed by three individual layers. The conversion layer is a pre-treated aluminum, which aims at promoting the bonding between aluminum and the primer. In this stage, however, the aviation industry uses chromium bath to form the conversion layer [I]. In order to eradicate the use of these damaging elements some countries, mainly European ones, have already taken action to eliminate this process within a few years, as the following standards state: Commission decision on the Implementation of the European Pollutant Emission Register (EPER) for IPPCD, Council Directive 67/548/EEC, Commission Regulation (EC) No 143/97, Council Directive 96/82/EC and Council Directive 76/769/EEC among others. The top coat and primer layers are used for decoration, to increase wear resistance and to protect the substrate from corrosion.

Several studies in literature have proposed alternative films to replace the chromium conversion layer. However, further investigation of new alternative coatings are still needed. Various chromate-free conversion coatings on aluminum have been developed, such as the ones based on zirconium, titanium, vanadium, cerium, and molybdenum coating as well as hybrid films silane-based coating [2-7]. Nevertheless, these coatings are still not as good as chromium when considering its properties.

In this context, the present paper proposes to create a new coating of hybrid film silane-based with the addition of graphene oxide particles to enhance performance considering wear and corrosion resistances [8-10]. This is not a new approach, but what was presented in this paper of silane-based hybrid film was already proved to have good performance [II-I5] and the addition of graphene oxide can be better than chromium conversion coating. Graphene oxide has very interesting properties for this purpose, such as high mechanical strength [16] and the ability to bind to other elements.

\section{EXPERIMENTAL PROCEDURES}

The samples of aluminum substrates AA2024 T3 $(2 \mathrm{~cm} \times 4 \mathrm{~cm} \times 0.1 \mathrm{~cm})$ were sanded using $\mathrm{SiC}$ abrasive paper (\# 400-1200). Samples were rinsed with deionized water, dried, rinsed once more with acetone, dried, then rinsed with ethanol and dried once again.

The procedure was based on the Staudenmaier method $[17,18]$. For the preparation of this technique sulfuric acid ( $\mathrm{H} 2 \mathrm{SO} 4)$ was provided by Fmaia, nitric acid ( $\mathrm{HNO} 3)$ by Merck, potassium chlorate $(\mathrm{KClO} 3)$ by Vetec Química Fina Ltda. And graphite (II $\mu \mathrm{m}$ d50) Micrograf HCI I by Nacional de Grafite Ltda.

The sulfuric and nitric acids were mechanically mixed for I hour. Graphite was added to the mixture that was kept in the mixer for 20 more minutes. Then, $\mathrm{KClO} 3$ was added and mechanically stirred for 24 hours. Finally, the product was washed with $\mathrm{HCl}$ at $10 \%$ to remove any remaining salts. Afterwards, the graphite oxide was kept within a dialysis membrane in water until $\mathrm{pH}$ around 6 was reached. The graphite oxide solution was then dried at $100^{\circ} \mathrm{C}$ for 3 hours.

The materials used for the sol-gel were tetraethoxysilane (TEOS, $\mathrm{C} 8 \mathrm{H} 20 \mathrm{SiO} 4)$ provided by Sigma Aldrich, 3 (trimethoxysilylpropyl) methacrylate (TMSPMA, $\mathrm{ClOH} 2 \mathrm{OSiO} 5)$ also by Sigma Aldrich, cerium nitrate $\left(\mathrm{Ce}(\mathrm{NO} 3)_{3}\right)$ from Merck, ethanol $(\mathrm{CH} 3 \mathrm{CH} 3 \mathrm{OH})$ from Synth, deionized water and graphite oxide both developed in the laboratory.

The hydrolysis reactions were conducted by alkoxide precursors TMSPMA and TEOS with $0.637 \mathrm{~g}$ and $4.23 \mathrm{~g}$, respectively. Then $\mathrm{Ce}(\mathrm{NO} 3) 3(0.086 \mathrm{~g})$, ethanol $(9.46 \mathrm{~g})$ and deionized water $(2.87 \mathrm{~g})$ were added and slowly mixed. After being hydrolyzed for 24 hours, graphite oxide was added into the sol with different concentrations ( I g.L I, 0.5 g.L-I, 0.25 g.L-I and 0 g.L-I) so that its influence could be evaluated. The suspension was maintained for 2 hours with magnetic stirring and then another 4 hours on ultrasound to disperse the graphite oxide until it became graphene oxide (GO).

Coated samples were prepared by using a dip coater (brand: Marconi -model: MA765). Samples were dipped in sol at a withdrawal speed of $10 \mathrm{~cm}$. min-I with a residence time of 10 minutes [ $19-2 \mid]$. Hybrid films were then thermally cured at $60^{\circ} \mathrm{C}$ for 10 minutes in a furnace (brand: De Leo - model: TLK48). Table I presents a description of the samples.

Table I. Nomenclature used for the samples

\begin{tabular}{ccc}
\hline Graphene oxide concentration & Film & Film on sample \\
\hline $\mathrm{I} .00 \mathrm{~g} \cdot \mathrm{L}^{-1}$ & $\mathrm{Si}-\mathrm{I}$ & $\mathrm{Al}-\mathrm{Si}-\mathrm{I}$ \\
$0.50 \mathrm{~g} \cdot \mathrm{L}^{-1}$ & $\mathrm{Si}-2$ & $\mathrm{Al}-\mathrm{Si}-2$ \\
$0.25 \mathrm{~g} \cdot \mathrm{L}^{-1}$ & $\mathrm{Si}-3$ & $\mathrm{Al}-\mathrm{Si}-3$ \\
Without graphene oxide & $\mathrm{Si}-\mathrm{u}$ & $\mathrm{Al}-\mathrm{Si}-\mathrm{u}$ \\
\hline
\end{tabular}


Hybrid film samples with and without addition of GO to the AA2024-T3 aluminum alloy were analyzed for morphology, electrochemical properties and wear behavior.

Morphological characterization was performed using a JEOL 65IOLV scanning electron microscopy (SEM) and $\mathrm{FEI}-$ Inspect $\mathrm{F} 50$ high-resolution scanning electron microscopy (SEM-FEG) with acceleration voltage of $20 \mathrm{kV}$ on top view.

TGA analyzes were performed using a Shimadzu TGA-50 equipment with temperature ranging from $23^{\circ} \mathrm{C}$ to $800^{\circ} \mathrm{C}$ and a heating rate of $10^{\circ} \mathrm{C}$.min- $\mathrm{I}$ in N2 flow of $50 \mathrm{~mL} / \mathrm{min}$.

The coating corrosion performance was evaluated using open circuit potential monitoring (OCP), polarization curves and electrochemical impedance spectroscopy in a $0.05 \mathrm{M} \mathrm{NaCl}$ solution. The AUTOLAB PGSTAT 30 potentiostat with a three-electrode cell and a platinum wire counter electrode was used. The saturated calomel electrode (SCE) was used as reference to perform the analyses. The area of the working electrode was of $0.626 \mathrm{~cm}^{2}$. Polarization curves used a potential interval between $-200 \mathrm{mV}$ (vs OCP) and $600 \mathrm{mV}$ (vs OCP) and a scan rate of I mV.s-I.For the electrochemical impedance spectroscopy (EIS) a sinusoidal signal of $10 \mathrm{mV}$ (rms signal) of amplitude was used, and a frequency ranging from $100 \mathrm{kHz}$ to $10 \mathrm{mHz}$ using a NOVA ${ }^{\circledR}$. EIS was performed every 24 hours for 5 days.
Wear tests were performed on a ball-on-plate test at room temperature. The equipment used was a CETR. The test was performed with a reciprocal linear motion of an alumina ball of $4.76 \mathrm{~mm}$ diameter, using constant force of $1.5 \mathrm{~N}$, frequency of $2 \mathrm{~Hz}$ and track length of $2 \mathrm{~mm}$. The average Hertzian contact stress was $135 \mathrm{MPa}$.

Finally, adhesion of the film to the substrate was evaluated according to the Brazilian ABNT NBRII003 standard. Samples were scratched (7 lines in each direction) with a stylus. Then a $55 \mathrm{gf.mm}-\mathrm{I}$ tape with minimal adhesion to steel was glued to the film and perpendicularly removed in order to analyze the efficiency of the film adhesion to the substrate, images were taken before and after the test.

\section{RESULTS AND DISCUSSION}

\section{I Morphology Characterization}

In Figure la and b, SEM showed GO particles present in the hybrid film, but these particles are observed as agglomerates. This is due to the high surface energy that promotes nanoparticle promote high tendency of agglomeration, increasing its mass and/or its volume in the film. FEG-SEM micrographs show in detail some GO sheets on the hybrid matrix.
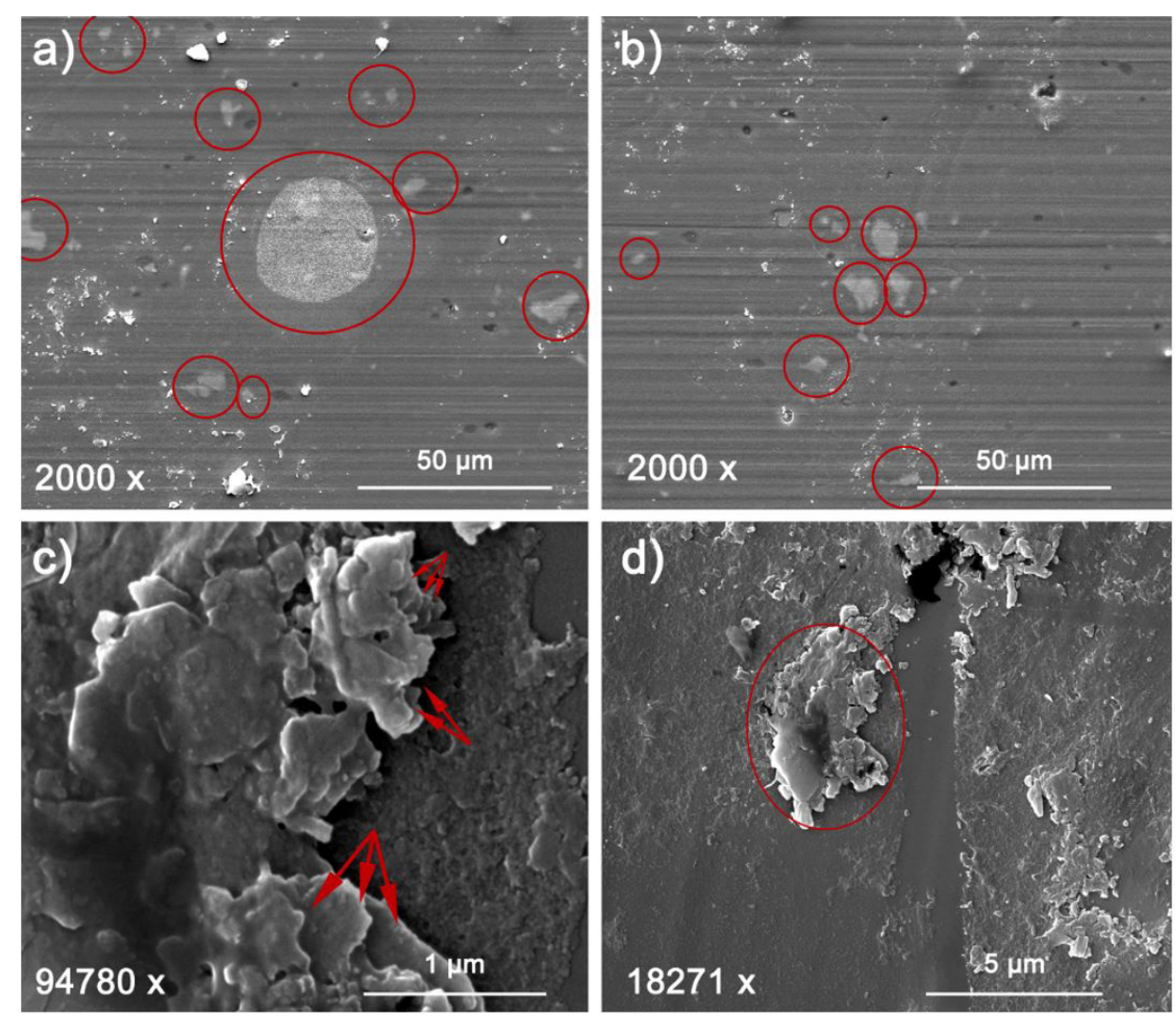

Figure I. SEM ( $a$ and b) and SEM-FEG (c and d) micrographs of hybrid film with particles of graphene oxide. 


\subsection{Thermal Characterization}

Figure 2 presents thermogravimetric analysis (TGA) characterization obtained from the samples studied under inert atmosphere (N2), and Table 2 shows the onset temperature (Tonset), maximum temperature (Tmax) and end temperature(Tendset) at each stage of degradation, in addition to the remaining residual percentage at the end of the analysis.

Five stages of degradation were observed in the graphene oxide (GO) sample. The first stage happened between $25{ }^{\circ} \mathrm{C}$ and $115^{\circ} \mathrm{C}$ and is related to the water evaporation between the layers of graphite oxide [22].

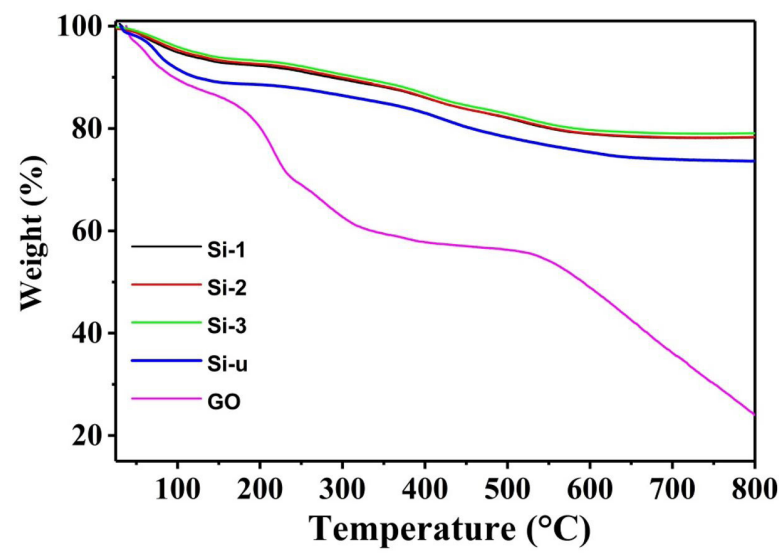

Figure 2. The thermogravimetric analysis (TGA) of samples studied in N2 atmosphere.
The next two stages happen between $155^{\circ} \mathrm{C}$ and $296{ }^{\circ} \mathrm{C}$ and are related to thermal decomposition of the oxygenated functional groups in $\mathrm{CO}$ and $\mathrm{CO}_{2}$ [22-24]. The last two stages happen between $310^{\circ} \mathrm{C}$ and $800^{\circ} \mathrm{C}$ and are associated with the removal of the more stable oxygenated groups and with the pyrolysis of the carbon structure in the graphite oxide [22,24].

Four stages of degradation were observed in the Si-u sample (without graphene). The first stage, happening between $27^{\circ} \mathrm{C}$ and $98^{\circ} \mathrm{C}$, is related to the evaporation of solvents (water and alcohol) present in the silane film. The other stages all happen between $155^{\circ} \mathrm{C}$ and $680^{\circ} \mathrm{C}$ and are related to the loss of intercalated species, to the breaking of surface group bonds, and to the degradation of the main chains of TEOS and TMSPMA.

The $\mathrm{Si}-\mathrm{I}$, $\mathrm{Si}-2$ and $\mathrm{Si}-3$ samples showed similar thermal behavior. Moreover, all samples presented similar silane degradation stages. However, samples with GO showed higher thermal stability and lower waste percentage when compared to Si-u sample. These results indicate that the presence of GO retards the degradation process of the film, probably due to decreased mobility of the silane chains, thus indicating a good film because of charge dispersion.

\subsection{Electrochemical Characterization}

The samples open circuit potential showed no significant difference among samples with and without film, as shown in Figure 3, since the system has not yet reached a steady state in the first hour and the protective coatings are still very effective [25].

Table 2. Thermal characteristics for the samples (TGA)

\begin{tabular}{|c|c|c|c|c|c|}
\hline \multirow{2}{*}{ Sample } & \multirow{2}{*}{$\begin{array}{c}\text { Thermal } \\
\text { degradation stage }\end{array}$} & \multicolumn{3}{|c|}{ Temperatures $\left({ }^{\circ} \mathrm{C}\right)$} & \multirow{2}{*}{ Residual mass (\%) } \\
\hline & & $\mathbf{T}_{\text {onset }}$ & $T_{\operatorname{mAx}}$ & $\mathbf{T}_{\text {endset }}$ & \\
\hline \multirow[t]{5}{*}{ GO } & $1^{\circ}$ & 25 & 63 & 115 & 88 \\
\hline & $2^{\circ}$ & 155 & 215 & 245 & 70 \\
\hline & $3^{\circ}$ & 250 & 275 & 296 & 60 \\
\hline & $4^{\circ}$ & 310 & 390 & 520 & 53 \\
\hline & $5^{\circ}$ & 580 & 712 & 800 & 25 \\
\hline \multirow[t]{3}{*}{$\mathrm{Si}-\mathrm{I}$} & $1^{\circ}$ & 26 & 60 & 86 & 92 \\
\hline & $2^{\circ}$ & 91 & 117 & 174 & 88 \\
\hline & $3^{\circ}$ & 230 & 498 & 570 & 78 \\
\hline \multirow[t]{3}{*}{$\mathrm{Si}-2$} & $1^{\circ}$ & 26 & 58 & 81 & 90 \\
\hline & $2^{\circ}$ & 94 & 121 & 170 & 84 \\
\hline & $3^{\circ}$ & 225 & 501 & 579 & 71 \\
\hline \multirow[t]{3}{*}{$\mathrm{Si}-3$} & $1^{\circ}$ & 25 & 56 & 80 & 90 \\
\hline & $2^{\circ}$ & 90 & 123 & 167 & 86 \\
\hline & $3^{\circ}$ & 229 & 497 & 572 & 77 \\
\hline \multirow[t]{4}{*}{ Si-u } & $1^{\circ}$ & 27 & 77 & 98 & 92 \\
\hline & $2^{\circ}$ & 155 & 198 & 272 & 86 \\
\hline & $3^{\circ}$ & 285 & 425 & 513 & 77 \\
\hline & $4^{\circ}$ & 520 & 616 & 680 & 73 \\
\hline
\end{tabular}


The theoretical model assumes that the rates of both anodic and cathodic processes are controlled by the kinetics of electron transfer reaction on the metal surface. The current is calculated from Equation I.

$\mathrm{I}=\mathrm{I} \_$corr $\left[\mathrm{e}^{\wedge}\left(\left(2.3\left(E-E \_(\text {corr })\right)\right) / \beta \_\mathrm{a}\right)-\mathrm{e}^{\wedge}\left(\left(-2.3\left(E-E \_(c o r r)\right)\right) / \beta \_c\right)\right](I)$

Where represent measured current, $\mathrm{E}$ is for electrode potential, Icorr for corrosion current (that can be evaluated from the point of intersection between the anodic and

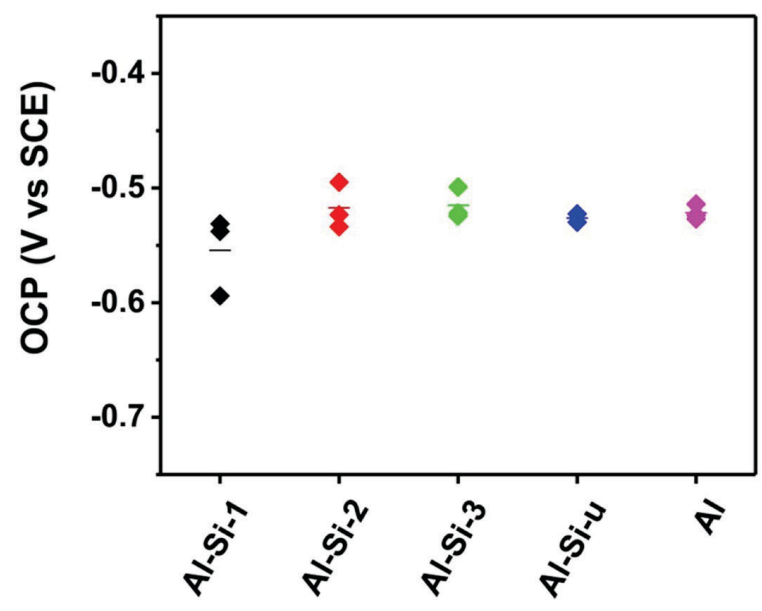

Figure 3. Open circuit potential of samples.

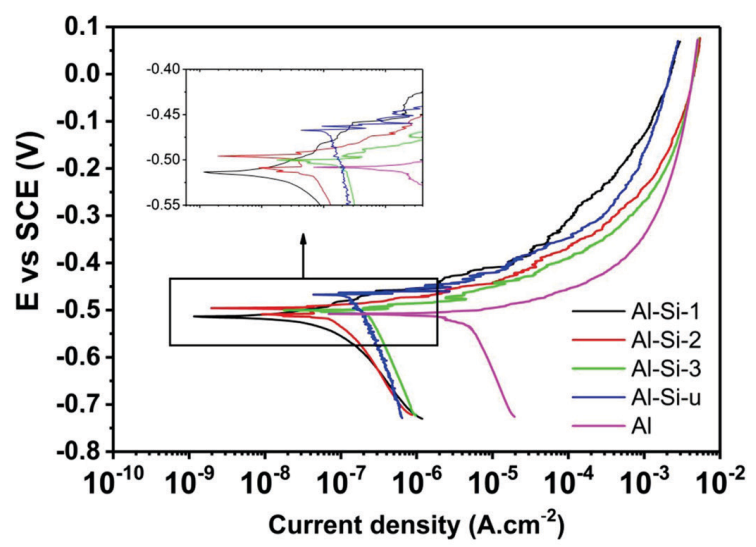

Figure 4. Potentiodynamic polarization curve. cathodic slopes on the tafel plot). Ecorr is the corrosion potential (which is the same as the open circuit potential for a corroding metal and is also a measure of the reactivity of the substrate under study) that can be read from the vertical axis of the anodic and cathodic intersection of the Tafel plot [26]. $\beta a$ and $\beta c$ are the anodic and cathodic Tafel constants obtained from slopes of the linear regions of the anodic and cathodic arms (Table 3) and is associated with redox reactions occurring at the metal/coating interface [27]. High Tafel constants correspond to low anodic and cathodic reactions and vice versa. The shape of the anodic or cathodic arms of the Tafel plot provides useful information about the mechanisms taking place.

The sample with the highest concentration of GO particles (Al-Si-I) showed the lowest corrosion current density (icorr), as shown in Figure 4. An explanation for this occurrence is that the graphene oxide difficults the passage of the electrolyte. However, even if it seemed to be a positive result, this analysis can hide a serious problem. Aluminum corrosion in this environment happens due to pitting corrosions (icorr) and in this case it is not a parameter to measure the severity of corrosion.

The Ecorr of the Al-Si-u and of the samples studied did not present great difference. Difference around $40 \mathrm{mV}$ is not enough to allow a clear distinction between among electrochemical behaviors of the samples examined [28]. However, the icorr of the samples Al-Si-I and Al-Si-2 decreased more than one third if compared with the no coated Al, what suggests a decrease in ion diffusion to the metal interface, possibly due to the presence of protective coatings. On a microscopic level, graphene reinforced coatings have lower permeability because of higher stiffness of chain motion during long or short-range motions. The increase in rubbery region modulus and glass transition temperature is correlated to the presence of rigid graphene fillers, as well as physical entanglements of the chains [29,30].

Higher lcorr values observed for the Al suggest poor corrosion resistance, hence increased flow of ions through coatings resulting in high corrosion rates. There is a linear relationship between lcorr and the corrosion rate, therefore high lcorr suggests high corrosion rates.

The presence of graphene in the coating creates obstacles for diffusing ions and limits flow of electro-active species to the metal interface, thereby decreasing corrosion rate.

Table 3. Tafel slope analysis

\begin{tabular}{cccccc}
\hline Sample & $\mathbf{E}_{\text {corr }}(\mathbf{m V})$ & $\mathbf{b}_{\mathbf{a}}(\mathbf{V} / \mathbf{d e c})$ & $\mathbf{b}_{\mathbf{c}} \mathbf{( V / d e c )}$ & $\mathbf{i}_{\text {corr }}\left(\mathbf{A} . \mathbf{c m}^{-2}\right)$ & $\begin{array}{c}\text { Polarization } \\
\text { resistance }\left(\Omega . \mathbf{c m}^{2}\right)\end{array}$ \\
\hline Al-Si-I & -514 & 0.692 & 0.056 & $2.42 \times 10^{-8}$ & $4.44 \times 10^{5}$ \\
Al-Si-2 & -496 & 0.054 & 0.046 & $4.42 \times 10^{-8}$ & $1.50 \times 10^{5}$ \\
Al-Si-3 & -500 & 0.116 & 0.018 & $8.75 \times 10^{-8}$ & $4.79 \times 10^{4}$ \\
Al-Si-u & -467 & 0.037 & 0.013 & $1.17 \times 10^{-7}$ & $4.59 \times 10^{4}$ \\
Al & -490 & 0.169 & 0.013 & $2.81 \times 10^{-6}$ & $8.00 \times 10^{3}$ \\
\hline
\end{tabular}


Furthermore, Al-Si-3 and Al-Si-u samples showed the worst performances among the coated samples studied (one order of magnitude lower in corrosion current density), suggesting that the coating had already failed and was no longer acting as a protective coat, thus allowing corrosion activity at the coating/metal interface $[3 \mid, 32]$.

Electrochemical impedance spectroscopy has been a widely used method for studying degradation and corrosive processes in metal / coating systems. EIS is a nondestructive technique that provides system's responses such as coating capacitance and resistance. Furthermore, information about diffusion process and charge transfer in the interface metal / coating can be obtained [33,34]. ElS can be used to study films with high corrosion resistance, for which the polarization curve method is limited, or as a complementary technique that enables advances in corrosion science [35].

The Bode plots at 24 hours and at 96 hours are shown in Figure 5. Al-Si-I and Al-Si-3 in a 24 hour immersion have two well-defined time constants. In low frequency, they represent the resistance and capacitance of the corrosion product layer [36]. This phenomenon has been observed by some authors $[37,38]$ who attributed it to a reduction in film thickness and / or conductivity of the electrolyte due to increased porosity of the film.

Two other time constants were observed in high frequency. They correspond to the charge transfer resistance and double-layer capacitance, respectively $[39,40]$.
The analyses of Al-Si-I and Al-Si-3 samples showed this phenomenon more evidently (which had a higher phase angle at high frequency during the 24 hour immersion). This may be associated with the fact that the presence of $\mathrm{GO}$ in the bath solution is incorporated into the crevices, gaps and micron holes of the coating, which prevents the corrosive medium $(\mathrm{Cl}-)$ from eroding the coating $[4 \mathrm{I}, 42]$. Moreover, the corrosion path is seriously distorted because of the incorporation of GO nanosheets in the silane matrix. The corrosive medium ( $\mathrm{Cl}-$ ) is blocked and cannot reach coatings and substrate, thus favoring the improvement of the corrosion resistance [43].

The impedance response is characteristic of a typical corroded surface in aggressive media with the precipitation of a corrosion product film [44]. Furthermore, Al-Si-u sample showed a smaller phase angle at high frequency than Al-Si-I and Al-Si-3 samples. This indicates that the coating has cracks / defects. In 96 hours of immersion that phenomenon disappears at high frequency in all samples analyzed indicating the penetration and attack of corrosive species across the coating layer. However, the 96 hour bode plot (Z) showed that Al-Si-I, Al-Si-2 and Al-Si-3 samples have better corrosion protective performance than Al-Si-u sample. Better corrosion resistance of the systems might be attributed to smaller grain size. Smaller grain sizes for coating can provide a much smaller cathode / anode surface ratio against localized corrosion due to the

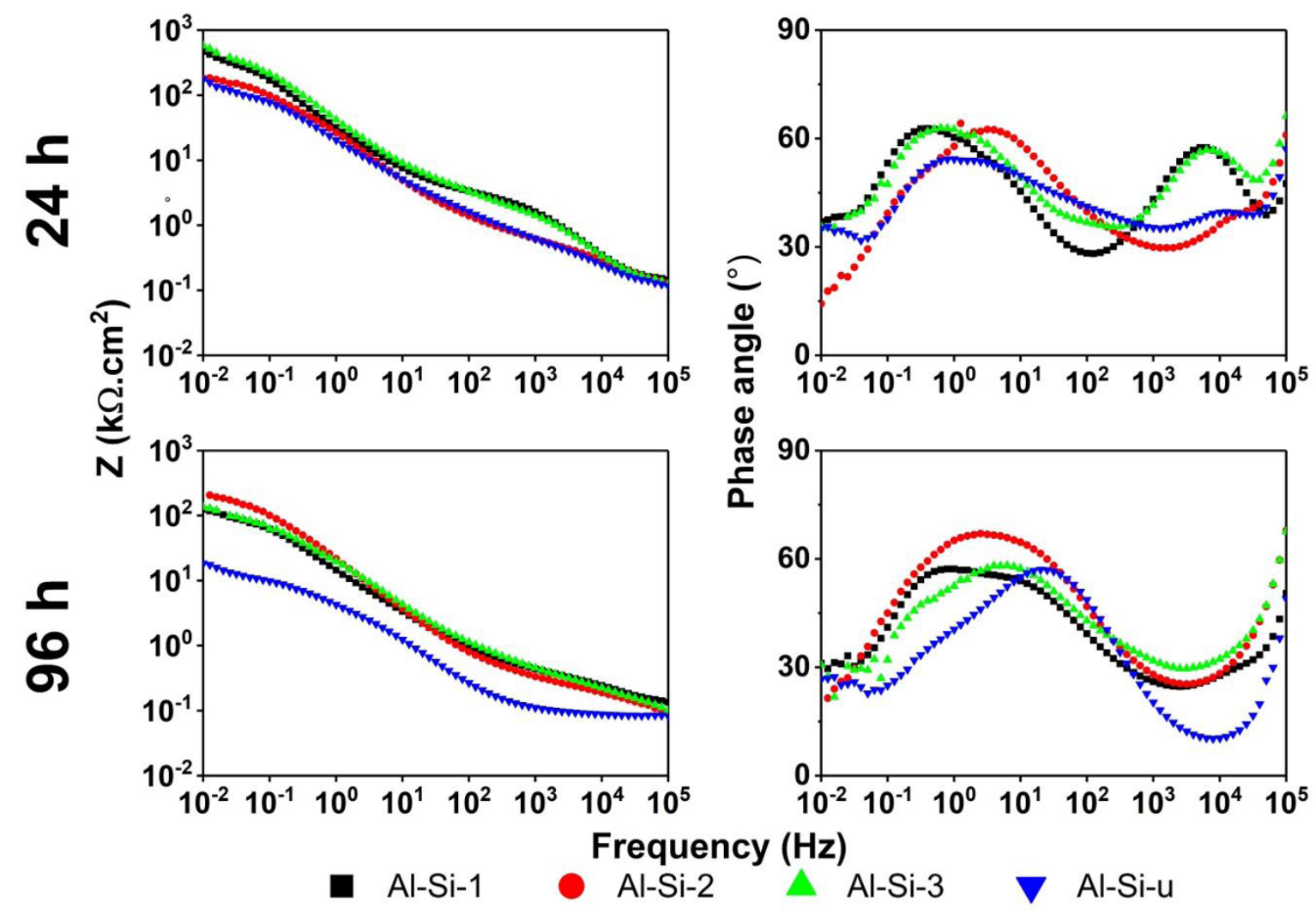

Figure 5. Impedance Bode plot in first column and phase angle Bode plot in second column in 24 hours and 96 hours of immersion. 
evenly distributed corrosion current, thus increasing the corrosion resistance $[45,46]$. In addition, when the coating is immersed in $\mathrm{NaCl}$ solution, $\mathrm{Cl}$ - which is a strong adsorption anion, tends to preferentially absorb on specific sites such as defects on the coatings [47].

\subsection{Wear Resistance}

The wear resistance on the aluminum alloy coated samples was analyzed by the monitoring of coefficient of friction in relation to the distance of the alumina ball. The measurement is stopped when there is an abrupt change of the friction coefficient and the change of the film was related to film fracture.

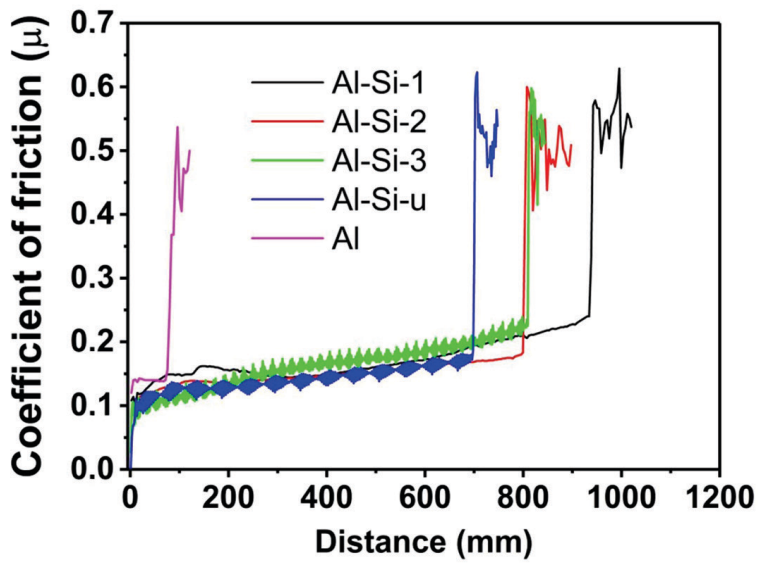

Figure 6. Coefficient of friction in the ball-on-plate test.
Wear analysis results was showed that the coating improve the useful life against wear (Al vs all other samples).

Other observation in wear analysis results was an increase in the particle concentration in the film and the wear resistance are directly correlated ( $\mathrm{Al}-\mathrm{Si}-\mathrm{I}>\mathrm{Al}-\mathrm{Si}-2>\mathrm{Al}-\mathrm{Si}-\mathrm{u}$ ), as shown in Figure 6. The samples with low concentration of particles in the hybrid film (Al-Si-3 and Al-Si-u) oscillated around the value of 0.1 until the moment of rupture of the film. This phenomenon may be related to the presence of a third body (which can be produced with cladding sliver) between the film and the ball. Thus, this phenomenon was annulled with an increase in the concentration of particles (Al-Si-2 and Al-Si-I). The Al-Si-2 sample had not phenomenon of oscillation, but it had the same useful life as the Al-Si-3 sample. Finally, besides not having the phenomenon of oscillation, the sample Al-Si-I had the best useful life.

The result confirms, as assumed, that the addition of GO to the coating improves wear resistance.

\subsection{Adhesion Test}

The images (Figure 7) obtained after the adhesion tests, according to NBRI 1003 standard, indicated that the composite film presents high adhesion to the aluminum substrate. The detection of silane in coatings is, in most of the cases, complicated because the film is almost transparent and of low thickness. The shade difference on the surface is probably due to the presence of a silane layer (dark regions) and lighter areas are silane layers that were removed by the tape test. All samples had less than $5 \%$ of their area removed, what corresponds to a $\mathrm{Gr}$ I degree, in compliance

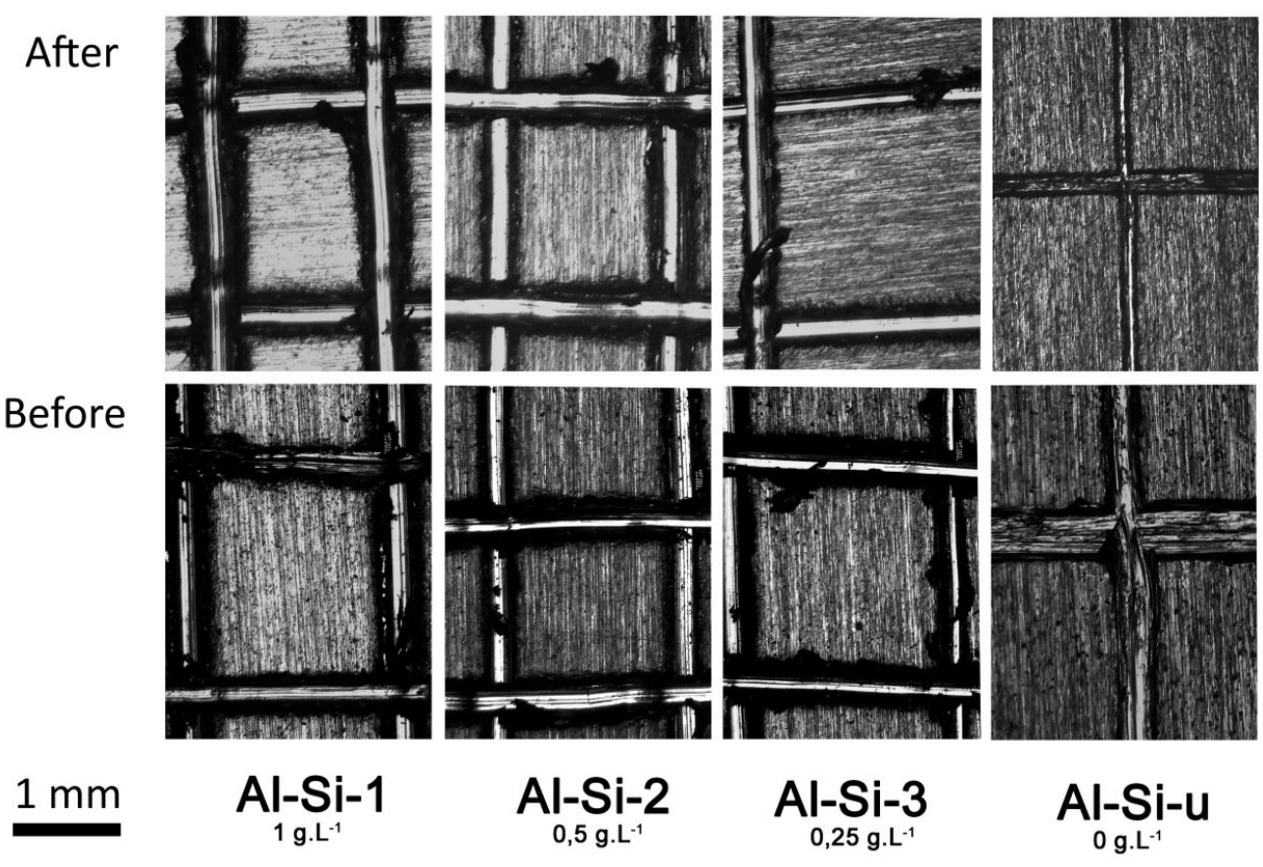

Figure 7. Images of adhesion test. 
with the NBRI I003 standard, which expresses a good coating adhesion. The addition of GO did not significantly change adhesion between coating and substrate.

Good coating adhesion confirms the results observed on electrochemical characterization. Good adhesion decreases the film movement on substrate avoiding, thus, the appearance of fissures which is responsible for slowing the corrosion expansion.

\section{CONCLUSION}

Aluminum alloys were coated with hybrid films obtained from a TEOS and TMSPMA sol prepared with $\mathrm{Ce}(\mathrm{NO} 3) 3$ inhibitor and the coating properties were effected by the addition of $\mathrm{GO}$.
The results obtained in this study showed that it was possible to verify through SEM-FEG that the coating on samples presented $\mathrm{GO}$ agglomeration. Another negative factor regarding corrosion resistance was that the graphene oxide was not homogeneously distributed on the hybrid film even after 4 hours on ultrasound.

This work demonstrated through electrochemical analysis (polarization curves and electrochemical impedance spectroscopy) that the addition of GO in this condition is not proved to improve the corrosion resistance. However, the composite coating showed strong adhesion to the substrate resulting in a strong bond between the substrate and the film. Nevertheless, the graphene oxide in film improved the wear resistance on a ball-on-plate test in up to $34 \%$.

\section{REFERENCES}

I Salnikow K, Zhitkovich A. Genetic and epigenetic mechanisms in metal carcinogenesis and cocarcinogenesis: nickel, arsenic, and chromium. Chemical Research in Toxicology. 2007;21:28-44.

2 Wang D, Bierwagen GP. Sol-gel coatings on metals for corrosion protection. Progress in Organic Coatings. 2009;64:327-338.

3 Hamdy AS, Doench I, Möhwald H. Intelligent self-healing corrosion resistant vanadia coating for AA2024. Thin Solid Films. 20II;520:1668-1678.

4 George FO, Skeldon P, Thompson GE. Formation of zirconium-based conversion coatings on aluminium and Al-Cu alloys. Corrosion Science. 2012;65:23 I-237.

5 Yi A, Li W, Du J, Mu S. Preparation and Properties of Chrome-Free Colored Na3AlF6 Conversion Coating on Aluminum Alloy. Applied Surface Science. 20I2;258:5960-5964.

6 Heller DK, Fahrenholtz WG, O'Keefe MJ. The effect of post-treatment time and temperature on cerium-based conversion coatings on Al 2024-T3. Corrosion Science. 2010;52:360-368.

7 Santa Coloma P, Izagirre U, Belaustegi Y, Jorcin JB, Cano FJ, Lapeña N. Chromium-free conversion coatings based on inorganic salts $(\mathrm{Zr} / \mathrm{Ti} / \mathrm{Mn} / \mathrm{Mo})$ for aluminum alloys used in aircraft applications. Applied Surface Science. 2015;345:24-35. http://dx.doi.org/10.1016/j.apsusc.2015.02.179.

8 Hou S, Su S, Kasner ML, Shah P, Patel K, Madarang CJ. Formation of highly stable dispersions of silane-functionalized reduced graphene oxide. Chemical Physics Letters. 2010;501:68-74.

9 Lou Y, Liu G, Liu S. Shen J, Jin W. A facile way to prepare ceramic-supported graphene oxide composite membrane via silane-graft modification. Applied Surface Science. 20I4;307:63I-637.

10 Wan Y-J, Gong L-X, Tang L-C, Wu L-B, Jiang J-X. Mechanical properties of epoxy composites filled with silanefunctionalized graphene oxide. Composites. Part A, Applied Science and Manufacturing. 2014;64:79-89.

I I Kunst SR, Beltrami LVR, Cardoso HRP, Veja MRO, Baldin EKK, Menezes TL, et al. Effect of curing temperature and architectural (monolayer and bilayer) of hybrid films modified with polyethylene glycol for the corrosion protection on tinplate. Materials Research. 2014;17:1071-108I.

12 Kunst S, Beltrami L, Longhy L, Cardoso H, Menezes T, Malfatti C. Effect of diisodecyl adipate concentration in hybrid films applied to tinplate. Chemical Industry \& Chemical Engineering Quarterly. 2016;01:13-13.

13 Kunst SR, Cardoso HRP, Beltrami LVR, Oliveira CT, Menezes TL, Ferreira JZ, et al. New Sol-gel formulations to increase the barrier effect of a protective coating against the corrosion and wear of galvanized steel. Materials Research. 2015; 18:138-150.

14 Kunst SR, Cardoso HRP, Veja MRO, Beltrami LVR, Menezes TL, Malfatti CF. The effects of curing temperature on bilayer and monolayer hybrid films: Mechanical and electrochemical properties Corrosion. Journal of Applied Electrochemistry. 20I4;44:759-77I. 
I5 Kunst SR, Beltrami LVR, Cardoso HRP, Menezes TL, Malfatti C F. UV Curing paint on hybrid films modified with plasticizer diisodecyl adipate applied on tinplate: the effects of curing temperature and the double layer. Industrial \& Engineering Chemistry Research. 2014;53:19216-19227.

16 Suk JW, Piner RD, An J, Ruoff RS. Mechanical properties of monolayer graphene oxide. ACS Nano. 2010;4:65576564.

17 Basso NRS, Fim F, Maraschin T, Pavoski G, Galland GB. A Few Layer Graphene Material Prepared by Thermal Reduction of GO. Proceedings of the 4th Graphene Conference; 2014 May 06-09; Toulouse, France.

18 Staudenmaier L. Verfahren zur Darstellung der Graphitsäure. Berichte der Deutschen Chemischen Gesellschaft. |898;3|:|48|-|487.

19 Kunst SR, Ludwig GA, Mato JF, Malfatti CF. Influencia del tiempo de hidrólisis en la obtención de película híbrida con adición de iones cerio para la protección de aceros galvanizados. Revista Facultad de Ingenieria Universidad de Antioquia (Medellín). 2013;69: I 24- I35.

20 Kunst SR, Matos JF, Antonini L, Ludwig GA, Fuhr L, Malfatti CF. Acero galvanizado pre-tratado con películas híbridas obtenido por recubrimiento por inmersión: influencia de la velocidad de retirada del substrato del sol. Avances En Ciencias e Ingeniería. 2013;4:97-107.

21 Kunst SR, Korb MA, Menezes TL, Tessaro G, Oliveira CT, Malfatti CF. Influência do processo de cura sobre as propriedades de filmes híbridos obtidos por sol-gel. Revista Escola de Minas. 2013;66:309-316.

22 Chen J, Yao B, Li B, Shi G. An improved Hummers method for eco-friendly synthesis of graphene oxide. Carbon. 2013;64:225-229.

23 Marcano DC, Kosynkin DV, Berlin JM, Sinitskii A, Sun Z, Slesarev A, et al. Improved Synthesis of Graphene Oxide. ACS Nano. 2010;4:4806-48I4.

24 Yang H, Li F, Shan C, Han D, Zhang Q, Niu L, et al. Covalent functionalization of chemically converted graphene sheets via silane and its reinforcement. Journal of Materials Chemistry. 2009; 19:4632.

25 Okafor PA, Singh-Beemat J, Iroh JO. Thermomechanical and corrosion inhibition properties of graphene/epoxy ester-siloxane-urea hybrid polymer nanocomposites. Progress in Organic Coatings. 20 15;88:237-244.

26 Tait WS. An introduction to electrochemical corrosion testing for practicing. Wisconsin: Pair O Docs Pubns; 1994. p. 79-94.

27 Singh-Beemat J, Iroh JO. The effect of morphology on the corrosion inhibition and mechanical properties of hybrid polymer coatings. Journal of Applied Polymer Science. 2013; I 28: 1616-1624.

28 Osório WR, Freitas ES, Spinelli JE, Garcia A. Electrochemical behavior of a lead-free Sn-Cu solder alloy in NaCl solution. Corrosion Science. 2014;80:71-8I.

29 Longun J, Iroh JO. Nano-graphene/polyimide composites with extremely high rubbery plateau modulus. Carbon. 2012;50:1823-1832.

30 Sahu SC, Samantara AK, Seth M, Parwaiz S, Singh BP, Rath PC, et al. A facile electrochemical approach for development of highly corrosion protective coatings using graphene nanosheets. Electrochemistry Communications. $2013 ; 32: 22-26$.

3I Schmuki P. From Bacon to barriers: a review on the passivity of metals and alloys. Journal of Solid State Electrochemistry. 2014;6:145-164.

32 El-Etre AY. Inhibition of aluminum corrosion using Opuntia extract. Corrosion Science. 2003;45:2485-2495.

33 Pacheco LG. Análise de viabilidade de implantação da técnica de espectroscopia de impedância eletroquímica para controle de processos de tratamento de superfície no setor aeroespacial [dissertation]. São Paulo: University of São Paulo; 2007.

34 Kunst SR, Cardoso HRP, Oliveira CT, Santana JA, Sarmento VHV, Muller IL, et al. Appl. Corrosion resistance of siloxane-poly (methyl methacrylate) hybrid films modified with acetic acid on tin plate substrates: Influence of tetraethoxysilane addition. Applied Surface Science. 2014;298: I - I I.

35 Kunst SR, Beltrami LVR, Cardoso HRP, Santana JA, Sarmento VHV, Müller IL, et al. Characterization of Siloxanepoly(methyl methacrylate) Hybrid Films Obtained on a Tinplate Substrate Modified by the Addition of Organic and Inorganic Acids. Materials Research. 2015;18:15I-163.

36 Qi K, Sun Y, Duan H, Guo X. A corrosion-protective coating based on a solution-processable polymer-grafted graphene oxide nanocomposite. Corrosion Science. 2015;98:500-506. 
37 Garcia SJ, Markley TA, Mol JMC, Hughes AE. Unravelling the corrosion inhibition mechanisms of bi-functional inhibitors by EIS and SEM-EDS. Corrosion Science. 20I3;69:346-358.

38 Yu Y-Y, Chen C-Y, Chen W-C. Synthesis and characterization of organic-inorganic hybrid thin films from poly(acrylic) and monodispersed colloidal silica. Polymer. 2003;44:593-60I.

39 Cambon J-B, Esteban J, Ansart F, Bonino J-P, Turq V, Santagneli SH, et al. Effect of cerium on structure modifications of a hybrid sol-gel coating, its mechanical properties and anti-corrosion behavior. Materials Research Bulletin. 2012;47:3170-3176.

40 Han Y-H, Taylor A, Mantle MD, Knowles KM. UV curing of organic-inorganic hybrid coating materials. Journal of Sol-Gel Science and Technology. 2007;43:I I I-I 23.

4I Aal AA, El-Sheikh SM, Ahmed YMZ. Electrodeposited composite coating of Ni-W-P with nano-sized rod- and spherical-shaped SiC particles. Materials Research Bulletin. 2009;44:I5I-I59.

42 Wang LY, Tu JP, Chen WX, Wang YC, Liu XK, Olk C, et al. Friction and wear behavior of electroless Ni-based CNT composite coatings. Wear. 2003;254:I289-1293.

43 Qu NS, Zhu D, Chan KC. Fabrication of Ni-CeO 2 nanocomposite by electrodeposition. Scripta Materialia. 2006;54:| |42|-| 425.

44 Fenelon AM, Breslin CB. The electrochemical synthesis of polypyrrole at a copper electrode: Corrosion protection properties. Electrochimica Acta. 2002;47:4467-4476.

45 Khabazian S, Sanjabi S. The effect of multi-walled carbon nanotube pretreatments on the electrodeposition of $\mathrm{Ni}-$ MWCNTs coatings. Applied Surface Science. 201 I;257:5850-5856.

46 Tao S, Li DY. Tribological, mechanical and electrochemical properties of nanocrystalline copper deposits produced by pulse electrodeposition. Nanotechnology. 2006;17:65.

47 Liu C, Su F, Liang J. Producing cobalt-graphene composite coating by pulse electrodeposition with excellent wear and corrosion resistance. Applied Surface Science. 2015;351:889-89.

Received: 20 Jun. 2017

Accepted: 17 Jul. 2018 